\title{
Unleashing the Utilitarian Motivations of Online Shopping among Indian Youth
}

\author{
K.A. Asraar Ahmed
}

Research Associate, VIT Business School, Vellore Institute of Technology, Vellore, asraarahmed.a@vit.ac.in

\section{Dr. A.S. Sathish}

Associate Professor of Marketing, VIT Business School, Vellore Institute of Technology, Vellore, sathish.as@vit.ac.in

\section{Doi:10.5901/mjss.2015.v6n2p391}

\begin{abstract}
The study explores Utilitarian motivation of young Indian consumers during online shopping. According to internet world statistics report December 2013, India has the second largest number of internet users in the world next to china indicating a high opportunity for online business for electronic retailers and highlights the importance of utilitarian shopping benefits are young Indian consumers looking for. The current research examines utilitarian motivation in Indian context among Indian youth. A structured questionnaire was distributed to a sample of 280 Under Graduate and Post Graduates students specifically to those who had prior online purchase experience. Confirmatory factor analysis has been done using LISREL 8.8. Finally results were recorded and implications were discussed.
\end{abstract}

Keywords: Online Shopping, Utilitarian Motivation, SEM, CFA, India, Youth

\section{Introduction}

Utilitarian consumer behavior has been described as ergic, task related, and rational (Batra and Ahtola 1991). A person tend to respond to situation if he or she believes that the utility of adopting internet services (in present context) is justified. Shopping if realized with benefits is termed as utilitarian motivation. Electronic Commerce has brought drastic changes in business across the world. Internet has helped many businesses to promote their products and services effectively. Online business in India is growing at a lightning speed. Boston Consulting Group survey reveals that urban consumers spends $\$ 30$ billion in India due to huge digital influence and will reach $\$ 150$ billion by 2016 . A recent study by Jamaluddin (2013) shows that adoption of e-commerce is growing rapidly among rural Indian consumer (especially farmers).As per Boston Consulting Group's Center for Consumer and Customer Insight survey men use more online purchase than women (32 percent versus 12 percent). Majority of users are from age 18 to 24 and lowest among older than 54. Indian consumers have started more online purchase so as per Forrester's report India's online spending will grow at a compound annual growth rate (CAGR) of about $50 \%$ in the next five years.

Since the online consumption in India is increasing rapidly over the years and due regards to the great deals offered by e retailers. According to TRAI (Telecom Regulatory Authority of India) July 2014 quarterly reports that there is increase in internet subscription (Both wireless and Wired Internet connection) from 238.71 million at the end of December-2013 to 251.59 million at the end of March 2014, so this shows that internet subscription are increasing at a rapid phase and it is important for electronic-retailers to understand as to what motivates Indian consumers during online shopping consumption. Motivational factors (for e.g. online trust, Prior online experience and impulse purchase intention, Quality Orientation) among Indian consumers to shop online has been studied by Thamizhvanan and Xavier (2012). Khare et al., (2012) have studied effect of age, gender on online shopping behavior. Ganguly et al. (2011) have studied the mediatory influence of online trust. Age, education, nature of Internet usage, and the time spent online also serve as key motivation for online air ticket purchase (Beldona et al., 2011). Dash and Saji (2007) have studied the effect of web site characteristics on online trust. Studies by various researchers to some extent explored the motivating factors that drives Indian Consumer to shop online, whereas studies on Utilitarian Motivation i.e. (Rational and Goal-oriented Motivation) and Hedonic Motivations i.e. (Pleasure, Fun Oriented Motivation) lacks emphasis and therefore in present paper we have focused on utilitarian motivation exclusively. This paper is divided into seven sections the first section consists of introduction, the second section with literature review, the third section consist of methodology, the fourth 
section with data analysis \& results discussion, fifth section consist of findings with discussions, sixth section consists of limitations, followed by conclusion and implications in seventh section. Thus the objectives of our study includes,

1. To study utilitarian motivations among young Indian online consumers.

2. To study the priority of utilitarian motivation opted by Young Indian consumers.

\section{Literature Review}

\subsection{Utilitarian Motivation in Online Context}

According to Holbrook \& Hirschman (1982) utilitarian consumer is a rational decision maker who is more concerned on benefits of product. The Utilitarian and Hedonic motivation was found to have great impact on consumer decision making Process (Childers et al., 2001; Arnold \& Reynolds, 2003; Van der Heijden 2004; Dhar \& Wertenbroch, 2000; To et al., 2007). Major scholars of marketing agreed that exploring Utilitarian and Hedonic motivation is worthwhile approach to understand consumer behaviour (Hirschman and Holbrook, 1982; Batra and Ahtola 1991; Crowley et al.1992; To et al., 2007; Van der Heijden 2004).

According to Dholakia et al., (2004) Utilitarian consumer shops online only when it suits their purpose. The two important dimension of shopping motivation such as utilitarian and hedonic motivations has been studied in physical store format by (Sheth 1991; Batra and Ahtola 1991; Babin et al., 1994; Park, 2004; Voss et al., 2003). Utilitarian Shoppers are those who shop attentively and purchase their needful product without any deviation (Wolfinbarger and Gilly, 2001). Crowley et al., (1992) empirically examined utilitarian and hedonic motivation were they found that utilitarian and hedonic motivations differ according to product type so Utilitarian and Hedonic components are important predictors of shopping attitudes and also commented that Batra and Ahtola (1991) measuring items are not effective enough to measure Hedonic and Utilitarian Dimensions. Dhar \& Wertenbroch (2000) conducted two experiments with proprietorship of two different products in a (Forfeiture) condition wherein both the experiments consumers showed positive preference towards hedonic goods. Batra and Ahtola (1991) developed an instrument which measure utilitarian and hedonic motivations where the result shows that both the dimensions such as utilitarian and hedonic are important in depicting consumer attitude towards brands. Consumers purchase goods and services for two basic reasons: (1) Pleasure (hedonic) and (2) contributory, (utilitarian) reasons (Batra and Ahtola 1990). Utilitarian value is an overall assessment of functional benefits, such as economic value, convenience, time savings (Jarvenpaa and Todd, 1997; Teo, 2001).Sheth (1991) distinguished motivations into functional and non-functional motivations. Functional motivations pertain to tangible aspects such as product assortment, product quality, convenience, price etc., while non-functional motivations comprise non-tangible aspects (such as store clientele, store reputation and promotions), social motivations (social interaction etc.) and personal motivations (enjoyable experiences). Babin et al. (1994) introduced two types of shopping values by developing a scale measuring both hedonic and utilitarian values obtained from the pervasive consumption experience of shopping. Traditionally the assessment of Utilitarian motivation is Practical, Purposeful, Active, Efficient and reasonable (Ryu et al., 2010).

Utilitarian Motivation have been studied in online context (Alba et al. 1997, Donthu and Garcla 1999; Swaminathan et al. 1999; Verhoef and Langerak 2001; Wolfinbarger and Gilly 2001; Overby \& Lee, 2006; To et al., 2007; Bridges and Florsheim 2008; Martínez-López et al. 2006, 2014). Childers et al 2001 conducted two experimental studies by using Technology Acceptance Model (Davis et al., 1989) wherein both the studies consumer preferred online shopping as (Fun, Joy, and Pleasure) and hence these are the factors which act as strong predictor towards online shopping (Monsuwe et al., 2004). Utilitarian consumer behavior has been described as ergic, task related, and rational (Batra and Ahtola 1991). Blake et al., (2005) suggested that utilitarian values has strong impact on online commerce. Online shoppers are more concerned about Utilitarian value (Blake et al., 2005; Martínez-López et al. 2014, Bernardo 2012, Beldona et al., 2011).Utilitarian motivated consumers seeks specific information whereas hedonically motivated consumers seek general information (Paden \& Stell 2010).They are utilitarian shoppers, looking for functional product benefits. Utilitarian Motivation has greater impact on Perceived value in Electronic service context (Bernardo et al., 2012).

Martínez-López et al. (2006) divided online consumption motivation into two categories mainly Utilitarian and Hedonic. "Utilitarian consumption motivation" is driven by functional, economic, rational, practical benefits. While "Hedonic motivations" are intrinsic, non-functional and emotional type.

\subsection{Utilitarian dimensions}

Babin et al. (1994) developed a scale to measure both Hedonic and Utilitarian Value. Utilitarian value was characterized 
as functional and extrinsic. Voss et al. (2003) established a new instrument with two Utilitarian and Hedonic Dimensions to measure attitudes of customers towards Brand and indicated that "Instrumental/Utilitarian" and "Affective/ Hedonic" are the two reasons why consumers purchase products and services. Four specific characteristics which fascinates Utilitarian shoppers are Convenience, Accessibility, Selection, Availability of Information and lack of sociality (Wolfinbarger and Gilly, 2001). To et al. (2007) further added two more (Cost saving and customization of product) constructs of utilitarian motivation. In hedonic terms consumer preferred more for offline shopping than online shopping and in utilitarian terms its vice versa. Martínez-López et al. 2014 developed a scale to measure Utilitarian Motivation by doing exhaustive literature review, and by conducting a Qualitative study and through expert opinion where he concluded nine Utilitarian Dimensions (Such as 1.Desire for control, 2. Convenience, 3. Assortment 4. Economy 5. Availability of information 6. Adaptability/ Customization 7. Payment Services 8. Absence of social interaction 9.Anonymity). According to study of Bridges and Florsheim (2008) and To et al., (2007) consumer were found to be more satisfied on shopping sites which promotes high utilitarian value such as Good value for money (Discounts,Deals,Offers), Convenience (Fast delivery, No physical risk involved) Broad selection (Comparison of products with different websites altogether) and availability (Products which are not available locally can be ordered through online), Information availability (all information related to products \& services from different websites together are available), Lack of sociability (No sales person interaction), Customized products or service (Products can be modified and tailor-made according customer requirement more conveniently) to its customer. They concluded that online stores must focus more on increasing utilitarian aspects rather than hedonic one. The resourcefulness, job specific and cost-effective characteristics of products and services serve as utilitarian motivation (Overby and Lee, 2006). According to Chandon et al., (2000) the utilitarian value depends on price and convenience.

\subsection{Convenience}

Convenience is defined as a ratio of inputs to outputs, time and effort being the relevant inputs (Seiders et al., 2000).Online shopping is considered as convenient only when it minimizes customer effort and facilitates quick response (Wolfinbarger and Gilly, 2001, Ganesh et al., 2010). Time factor plays crucial role among consumers to choose shopping channels McDonald (1994).Consumers cautiously measures benefits against the cost in store shopping (Dodds et al 1991). Utilitarian consumer chooses nontraditional shopping channel (Such as Catalog retailing Eastlick \& Feinberg, 1999) and online shopping (Monsuwé et al 2004) because of high benefits. Wang et al (2006) "Variety-seeking" consumers were more concerned about Convenience compare to other types of consumers.

\subsection{Availability of information}

Alba et al. (1997) studied effects of consumer, retailer and manufacturer behaviour on Interactive home shopping media where they suggests that consumer positively "interact" with these new technology which benefits them to seek information about products and services with 24 hours of "Availability" and "Accessibility" at one side and on the other side this new media differs in many evocative ways compare to old-style shopping. Availability of information (Anckar 2003; Messinger \& Narasimhan, 1997; To et al., 2007; Martínez-López et al. 2014) and price comparison tools (Noble et al., 2005, Martínez-López et al. 2014) benefits consumer. Privacy is considered as most important factor in online business (Sheehan 2002; Wolfinbarger and Gilly 2003).Searching for information is the key motivation among consumers to go for an online as well as offline consumption (Alba et al., 1997; Hoffman \& Novak, 1996; Kau and Tang 2003; To et al., 2007). Availability of information is key dimension for B2C websites (Ranganathan and Ganapathy 2002).Quick and easy way to search for product information has resulted in increased purchase of expensive products irrespective of price (Lynch and Ariely 2000; Monsuwe et al., 2004). Consumer search more information through online compare to traditional stores (Kau and Tang 2003; Rohm and Swaminathan 2004, Bernardo et al., 2012). Search for information through internet medium was preferred more by consumers because of its advantageous features compare to printed one (Hoque and Lohse 1999). Those with utilitarian motivations may be more likely to seek value from what they achieve through their use of the community, such as meeting information needs through browsing (Kim 2006).

\subsection{Socio Demographic Factors}

Males were found to be more convenience seekers than females according to study Swaminathan et al. (1999). Women's found to be more motivated to shop online than males Alreck and Settle (2002). Online shoppers were found to be younger than average and more likely to be male (Thamizhvanan and Xavier 2012; Khare et al., 2012). Utilitarian motivations were found to be predominant factors for products like personal care, consumer electronics and spectacles 
during online consumption among Indian youth (Sane \& Chopra 2014).Education is important factor for online shoppers (Li et al., 2012).Price was considered to be most important criteria for shoppers during online consumption (Batra \& Ahtola, 1991; Rajesh et al., 2013).

\subsection{Economic Value}

Availability of price comparison tools drives consumers to shop online (Anckar 2003; Martínez-López et al. 2014) and it triggers consumers get diverge to other shopping channels (Waldfogel and Chen 2006). Consumers prefer Online shopping channels more because it offers better price than offline channels (Noble et al., 2005; Martínez-López et al. 2014). Price consciousness is the degree to which consumers focus exclusively on paying low prices (Beldona et al., 2011; Rajesh et al., 2013). Cost saving is important factor for consumers during online shopping (Monsuwe et al., 2004).

\section{Research Methodology}

The researchers wanted to know the utilitarian motivations of youth towards online shopping and the approach of gathering primary data becomes necessary. The greatest strength of survey method lies in its versatility, recording opinions and facts about an event. An online survey was deployed among the respondents to elicit their responses. A structured questionnaire was distributed to a convenience sample of undergraduate and post graduate students of a Private University only to those who have a prior online purchase experience. A total of 350 questionnaires were sent through online forms out of which only 280 responses were returned and incomplete responses were excluded from the study. The measuring instrument used in this study was adapted from Martínez López et al. (2014) to suit the objective of our study, The instrument contains 36 items each items were rated on 5 point Likert scale ranging from 1 (Strongly Disagree), 2 (Disagree), 3 (Neutral), 4 (Agree) and 5 (Strongly Agree).The utilitarian motivation items consist of nine subscales (which is termed as Meta-Motivations according to Martínez López et al. (2014) comprising of Desire for Control (3items), Convenience(6 items), Assortment (4 items), Economy (5 items), Availability of Information( 7 items), Adaptability and Customization (4 items), Payment services (2 items), Absence of social interaction(2 items), and Anonymity (3 items).

\section{Data Analysis and Results}

Confirmatory factor analysis by means of LISREL 8.8 (Joreskog and Sörbom, 2006) and SEM was carried out with the obtained data and measurement items of those values that are less than 0.5 are removed as per Hair et al., (1998). None of the items were deleted from the adapted questionnaire all 36 items values were above 0.5 (see Appendix 2). Confirmatory Factor Analysis is usually performed to test the measurement model underlying a measure, whilst the structural model is tested with SEM. To determine the fitness of model a first order and second order Confirmatory Factor Analysis (CFA) was performed using LISREL 8.80 (Jöreskog \& Sörbom, 1996) also see (Appendix-2).The items were analyzed using statistical tool (SPSS Version 22) the reliability test was performed on the items of the Utilitarian Motivation questionnaire. All Items values showed high ( $\alpha>0.80$ see Table 5) (Nunnally, 1978). Age, Gender, Education, were single item measures, Gender was coded dichotomously. The final measurement model obtained was close to good fit $(X 2=1197$, degrees of freedom $[\mathrm{df}]=551, \mathrm{pb} .001$; comparative fit index [CFI] $=.98$; root mean square error of approximation $[\mathrm{RMSEA}]=.063 \mathrm{GFI}=.80 \mathrm{NFI}=.89$, Relative fit index RFI= .88. The value of Standardized Root Mean Residual $[R M R]=0.057$ which should be less than .05 (Byrne, 1998). According to Cole (1978) GFI value 0 to 1 is considered to be good fit but Jöreskog \& Sörbom (2006) GFI value greater than 0.9 is considered to be the good fit. According Hair et al (1998) Goodness of fit value greater than 0.8 is considered to be good fit. So the results shows close to Goodness of fit (GFI=.80) and may be due to less number of samples as suggested by Sharma et al., (2005). According to Hu and Bentler (1999), NFI value >.95 is considered as extremely good fit. According to Byrne, (1998) RMR value $<.05$ is preferred and the results of the study gets a valid support. 
Table 1. Descriptive statistics

\begin{tabular}{|c|c|c|c|}
\hline \multicolumn{4}{|c|}{ Descriptive statistics } \\
\hline \multirow{4}{*}{ Gender } & & Frequency & Percent \\
\cline { 2 - 4 } & Male & 141 & 50.4 \\
\cline { 2 - 4 } & Female & 139 & 49.6 \\
\cline { 2 - 4 } & Total & 280 & 100 \\
\hline \multirow{4}{*}{ Age } & $18-20$ & 127 & 45.4 \\
\cline { 2 - 4 } & $21-23$ & 144 & 51.4 \\
\cline { 2 - 4 } & $24-26$ & 9 & 3.2 \\
\cline { 2 - 4 } & Total & 144 & 100 \\
\hline \multirow{4}{*}{ Qualification } & PG & 99 & 35.4 \\
\cline { 2 - 4 } & UG & 181 & 64.6 \\
\cline { 2 - 4 } & Total & 280 & 100 \\
\hline \multirow{4}{*}{ Time period of internet usage } & Less than 2 Years & 62 & 22.1 \\
\cline { 2 - 4 } & Less than 3 Years & 21 & 7.5 \\
\cline { 2 - 4 } & Less than 6 Months & 53 & 19.9 \\
\cline { 2 - 4 } & $2-2.5$ Years & 41 & 14.6 \\
\cline { 2 - 4 } & 6-12 Months & 71 & 25.4 \\
\cline { 2 - 4 } & More than 3 Years & 31 & 11.1 \\
\cline { 2 - 4 } & Total & 280 & 100 \\
\hline
\end{tabular}

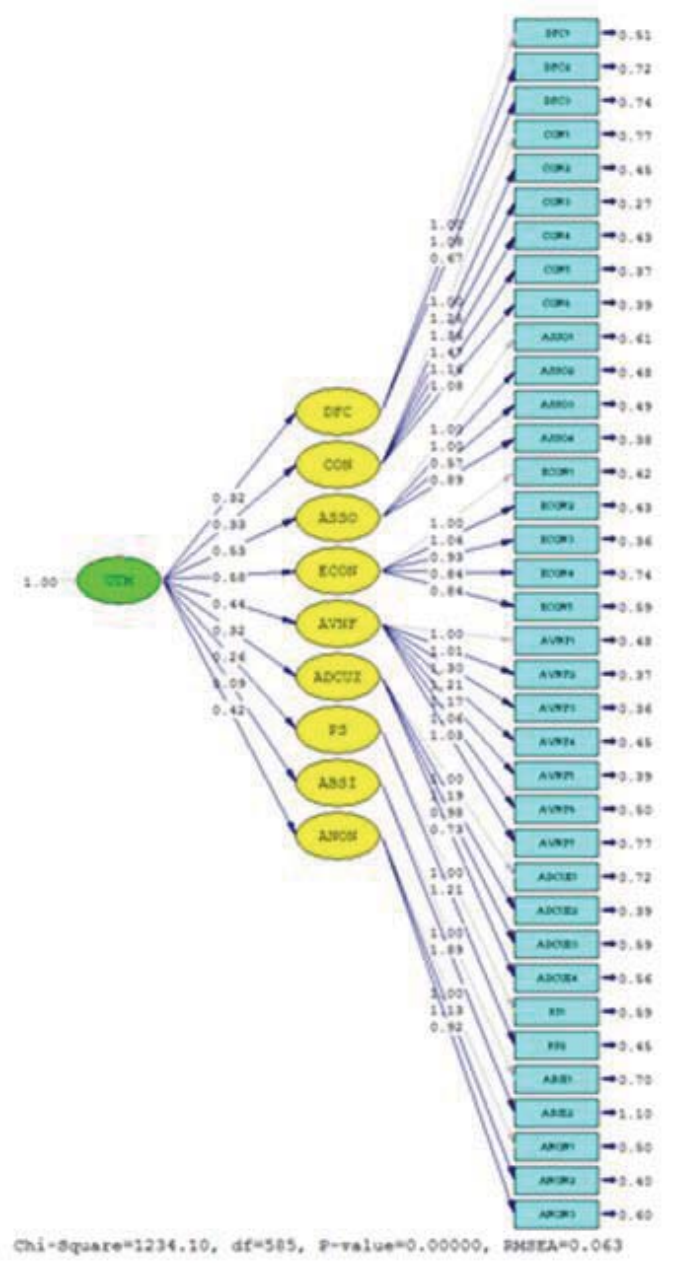

Figure 1. Path Diagram 
From Table. 2 we can observe that some of our index values scores are extremely good satisfying recommended values (such as RMSEA, P-Value for Test of Close Fit, IFI, and CFI) and other important indexes (such as GFI, RMR, RFI, PNFI, $\mathrm{NNFI}, \mathrm{NFI}$ ) values were close to good ness of fit.

Table. 2. Fit Indices of CFA Model

\begin{tabular}{|l|c|c|}
\hline Goodness of Fit Statistics & Score & Recommended Values \\
\hline Degrees of Freedom & 585 & as low as possible \\
\hline Minimum Fit Function Chi-Square & $1228.81(\mathrm{P}=0.0)$ & as low as possible \\
\hline Root Mean Square Error of Approximation (RMSEA) & $0.063^{\star \star}$ & $<0.08$ (Hu and Bentler, 1999) \\
\hline P-Value for Test of Close Fit (RMSEA < 0.05) & $=0.00^{* *}$ & (RMSEA <0.05) \\
\hline Normed Fit Index (NFI) & $0.89^{\star}$ & $>.95($ Hu and Bentler, 1999). \\
\hline Non-Normed Fit Index (NNFI) & $0.93^{\star}$ & $>.95($ Hu and Bentler, 1999). \\
\hline Parsimony Normed Fit Index (PNFI) & $0.82^{\star}$ & $>.90$ (Hair et al 1995) \\
\hline Comparative Fit Index (CFI) & $0.94^{\star *}$ & $>.90$ (Hu and Bentler, 1999) \\
\hline Incremental Fit Index (IFI) & $0.94^{\star *}$ & $>.90$ \\
\hline Relative Fit Index (RFI) & $0.88^{\star}$ & $>.90$ \\
\hline Root Mean Square Residual (RMR) & $0.057^{\star}$ & $<.05$ (Byrne, 1998) \\
\hline Goodness of Fit Index (GFI) & $0.8^{\star}$ & $>.90$ \\
\hline Adjusted Goodness of Fit Index (AGFI) & 0.78 & Higher the better \\
\hline Parsimony Goodness of Fit Index (PGFI) & 0.71 & Higher the better \\
\hline
\end{tabular}

Acceptability: ( $\left.{ }^{*}\right)$ Bordering Value and $\left(^{* *}\right)$ highly acceptable value

\section{Discussions}

The objective of our study was to find utilitarian motivation among Indian Youths. Thus from results it is concluded that young Indian consumers gives top most priority to economic value for engaging in online shopping (Maximum factor loading value for Economy was indicated as "ECON" in Structural Model has value of 0.58). From our Confirmatory Factor Analysis results we see that only hierarchical ordering of utilitarian motivations differs compare to results of Martínez López et al., (2014). Consumers in our study has prioritized "Economy" as a major concern over "Assortment" in contrast to the study conducted by Martinez Lopez et al., (2014) online customers have prioritized Assortment over Economy. This clearly indicates the priorities connected to a different set of audience.

\section{Limitations of the Study and Suggestions for Future Research}

There is always limitation exists in research studies, thus in our study the limitations were our small sample size with which generalization cannot be made. Though there is gender balance in our study sample to some extent, but it does not fully reflect demographic profile of Young Indians in regional point of view. We have considered only the urban samples for the study and not rural samples, thus can be of a limitation. Future research on utilitarian motivation should focus on demographically balanced sample (Such as should include all socio demographic information such as Age, Gender, Income, Marital status, Profession). Samples from a rural level can give a much different perspective and a scope for understanding a rural blend. As far our research is concerned the instrument emerged as a good fit ([RMSEA] $=0.063 \mathrm{GFI}=0.80 \mathrm{NFI}=.89 \mathrm{RFI}=0.88$ ) and just with a difference in hierarchical ordering of utilitarian motivation structure. As recommended by Martínez López et al. (2014) adequacy of its utilitarian motivation structure should be further discussed and refined. In future studies the sample should include respondents from all sectors to generalize the results.

\section{Conclusion \& Implications}

Our empirical study revealed that there exists a difference in hierarchy of Utilitarian motivation dimensions when compared to the study conducted by Martínez-López et al., (2014). Thus from the results we can conclude that top five priorities e retailer must take into notice of the priorities as per the listing 1.) Indian young consumers are more concerned about economic aspects of utilitarian motivation. So e-tailers must provide good price offering to attract these customers. Discount coupons and competitive prices are major drivers for online shopping (Martínez-López et al., 2014). 2.) Assortment is the second most concerned part of these Indian consumers so e retailers must design their website in such a way that it should be simple and easy instead of being too complex. 3.) Availability of information is the third most 
concern for young Indian consumer when they look for products online it important to furnish each and every single data about the product in the website because the consumer cannot physically touch and feel product (Martínez López et al. 2014). 4.) Anonymity is the fourth most important concern for Indian young consumers so e retailers must make sure that the customers search the products privately without identifying themselves till the time of purchase (Martínez López et al. 2014). 5.) Convenience is the top fifth most important concern for young Indian consumers so e retailer must make sure that they make products available for them 24/7 even through mobile apps (Martínez López et al. 2014). Our study explored the possible utilitarian motivation of young online shoppers with a hierarchical difference of their customer choice indicating their preferences. Thus throws light on the aspects that drives young consumers shopping preferences. This hierarchical list makes a point for e-tailers in understanding the nuances of changing needs of their consumers and compels too woo them, thereby serving them with loads of comfort.

\section{References}

Alba, J., Lynch, J., Weitz, B., Janiszewski, C., Lutz, R., \& Sawyer, A. (1997). Interactive home shopping: Consumer, retailer, and manufacturer incentives to participate in electronic marketplaces. Journal of Marketing, 61 (3): 38.

Anckar, B. (2003). Drivers and inhibitors to ecommerce adoption: Exploring the rationality of consumer behavior in the electronic marketplace. ECIS 2003 Proceedings, 24.

Babin BJ, Darden WR, Griffin M (1994). Work and/or fun: Measuring hedonic and utilitarian shopping value. J Consum. Res. 20:644-656.

Batra R, Ahtola OT (1990). Measuring the hedonic and utilitarian sources of consumer attitudes. Mark. Lett. 2:159-170.

Batra, Rajeev and Olli T. Ahtola (1991). Measuring the Hedonic and Utilitarian Sources of Consumer Attitudes. Marketing Letters, 2(April), 159170.

Beldona, S., Racherla, P., \& Mundhra, G. D. (2011). To buy or not to buy: Indian consumers' choice of online versus offline channels for air travel purchase. Journal of Hospitality Marketing \& Management, 20(8), 831-854.

Bernardo, M., Marimon, F., and Alonso-Almeida, M. (2012) Functional quality and hedonic quality: a study of the dimensions of e-service quality in online travel agencies. Information \& Management, 49, 7-8, 2012, 342-347.

Blake, B. F., Neuendorf, K. A., \& Valdiserri, C. M. (2005). Tailoring new websites to appeal to those most likely to shop online. Technovation, 25(10), 1205-1214.

Bridges, E., \& Florsheim, R. (2008). Hedonic and utilitarian shopping goals: the online experience. Journal of Business Research, 61(4), $309-314$.

Byrne, B.M. (1998), Structural Equation Modeling with LISREL, PRELIS and SIMPLIS: Basic Concepts, Applications and Programming. Mahwah, New Jersey: Lawrence Erlbaum Associates.

Chandon, P., Wansink, B. and Laurent, G. (2000), "A benefit congruency framework of sales promotion and effectiveness", Journal of Marketing, Vol. 64 No. 4, pp. 65-81.

Cole, D. A. (1987). Utility of confirmatory factor analysis in test validation research. Journal of consulting and clinical psychology, 55(4), 584.

Crowley, A. E., Spangenberg, E. R., \& Hughes, K. R. (1992). Measuring the hedonic and utilitarian dimensions of attitudes toward product categories. Marketing Letters, 3(3), 239-249.

Dash, S., \& Saji, K. B. (2008). The role of consumer self-efficacy and website social-presence in customers' adoption of B2C online shopping: an empirical study in the Indian context. Journal of International Consumer Marketing, 20(2), 33-48.

Davis, F. D., Bagozzi, R. P., \& Warshaw, P. R. (1989). User acceptance of computer technology: a comparison of two theoretical models. Management science, 35(8), 982-1003.

Dhar, R., \& Wertenbroch, K. (2000). Consumer choice between hedonic and utilitarian goods. Journal of marketing research, 37(1), 60-71.

Donthu, N., \& Garcla, A. (1999). The internet shopper. Journal of advertising research, 39, 52-58.

Dodds, W. B., Monroe, K. B., \& Grewal, D. (1991). Effects of price, brand, and store information on buyers' product evaluations. Journal of Marketing Research, 28 (3), 307.

Ganesh, J., Reynolds, K. E., Luckett, M., \& Pomirleanu, N. (2010). Online shopper motivations, and e-store attributes: an examination of online patronage behavior and shopper typologies. Journal of Retailing, 86(1), 106-115.

Ganguly, B., Dash, S., \& Cyr, D. (2011). The influence of website characteristics on trust in online travel portals in India: the moderating role of demographic and psychographic variables. Tourism Recreation Research, 36(1), 57-68.

Hair Jr, J. F., Anderson, R. E., Tatham, R. L., \& William, C. (1995). Black (1995), Multivariate data analysis with readings. Prentice Hall. New Jersey, USA. pp, 14, 130-133.

Hoffman, E. L. \& Novak, T. P. (1996). Marketing in hypermedia computer mediated environments: Conceptual foundations. Journal of Marketing, 60 (3), 50.

Hirschman E, Holbrook M (1982). Hedonic consumption emerging concepts, methods and prepositions. J. Mark. 46:92-101

Hu, L.T. and Bentler, P.M. (1999), "Cutoff Criteria for Fit Indexes in Covariance Structure Analysis: Conventional Criteria versus New Alternatives," Structural Equation Modeling, 6 (1), 1-55.

Jamaluddin, N. (2013). Adoption of E-commerce Practices among the Indian Farmers, a Survey of Trichy District in the State of Tamilnadu, India. Procedia economics and finance, 7, 140-149.

Jarvenpaa, S. L., \& Todd, P. A. (1996). Consumer reactions to electronic shopping on the World Wide Web. International Journal of electronic commerce, 59-88.

Jöreskog, K.G. \& Sörbom, D. (2006). LISREL 8.8 for Windows [Computer software]. Skokie, IL: Scientific Software International, Inc.

Jöreskog, K.G. \& Sörbom, D. (1996). LISREL 8 User reference guide, Scientific Software International, Inc.

Kau, A. K., Tang, Y. E., \& Ghose, S. (2003). Typology of online shoppers. Journal of Consumer Marketing, 20(2), 139-156.

Khare, A., Khare, A., \& Singh, S. (2012). Attracting shoppers to shop online-Challenges and opportunities for the Indian retail sector. Journal of 
Internet Commerce, 11(2), 161-185.

Kim, H. S. (2006). Using hedonic and utilitarian shopping motivations to profile inner city consumers. Journal of Shopping Center Research, 13(1), 57-79.

Li, M., Dong, Z.Y. and Chen, X. (2012), "Factors influencing consumption experience of mobile commerce: a study from experiential view", Internet Research, Vol. 22 No. 2, pp. 120-41.

Martinez-Lopez, F. J., Luna-Huertas, P., \& Martinez, F. J. (2006). Motivations for consumption behaviours on the web: a conceptual model based on a holistic approach. International Journal of Electronic Marketing and Retailing, 1(1), 3-20.

Martínez-López, F. J., Pla-García, C., Gázquez-Abad, J. C., \& Rodríguez-Ardura, I. (2014). Utilitarian motivations in online consumption: Dimensional structure and scales. Electronic Commerce Research and Applications, 13(3), 188-204.

McDonald, W. J. (1995). Time use in shopping: the role of personal characteristics. Journal of Retailing, 70(4), 345-365.

Messinger, P. R. \& Narasimhan, C. (1997). A model of retail formats based on consumers' economizing on shopping time. Marketing Science, 16 (1), 1.

Noble, S. M., Griffith, D. A., \& Weinberger, M. G. (2005). Consumer derived utilitarian value and channel utilization in a multi-channel retail context. Journal of Business Research, 58 (12), 1643.

Nunnally, J. C. (1978). Psychometric theory (2nd ed.). New York: McGraw-Hill.

Oliver, R. L., Rust, R. T., \& Varki, S. (1997). Customer delight: foundations, findings, and managerial insight. Journal of Retailing, 73(3), 311-336.

Overby, J. W., \& Lee, E. J. (2006). The effects of utilitarian and hedonic online shopping value on consumer preference and intentions. Journal of Business Research, 59(10), 1160-1166.

Paden, N., \& Stell, R. (2010). Virtual Cart Abandonment: Addressing Hedonic and Utilitarian Shopping Motives. Proceedings of ASBBS, 17(1), 883-887.

Park C (2004). Efficient or enjoyable?: Consumer values of eating-out and fast food restaurant consumption in Korea. Int. J. Hosp. Manag., 23:8794.

Ranganathan, C., \& Ganapathy, S. (2002). Key dimensions of business-to-consumer web sites. Information \& Management, 39(6), 457-465.

Rohm, A. J., \& Swaminathan, V. (2004). A typology of online shoppers based on shopping motivations. Journal of business research, 57(7), 748757.

Ryu K, Han H (2010). Influence of the quality of food, service, and physical environment on customer satisfaction and behavioral intention in quick-casual restaurant: Moderating role of perceived price. J. Hosp. Tourism. Res. 34(3):310-329.

Sane, V., \& Chopra, K. (2014). Analytical Study of Shopping Motives of Young Customers for Selected Product Categories with Reference to Organized Retailing in Select Metropolitan Select Cities of India. Procedia-Social and Behavioral Sciences, 133, 160-168.

Seiders, K., Berry, L. L., \& Gresham, L. G. (2000). Attention, retailers! How convenient is your convenience strategy? Sloan Management Review, 41(3), 79-90.

Sharma, S., Mukherjee, S., Kumar, A., \& Dillon, W. R. (2005). A simulation study to investigate the use of cutoff values for assessing model fit in covariance structure models. Journal of Business Research, 58(7), 935-943.

Sheehan, K.B. (2002), "Towards a typology of internet users and online privacy concerns", The Information Society, Vol. 18, pp. 21-32.

Sheth, J. N., Newman, B. I., \& Gross, B. L. (1991). Why we buy what we buy: a theory of consumption values. Journal of business research, 22(2), 159-170.

Swaminathan, V., Lepkowska-White, E., \& Rao, B. P. (1999). Browsers or buyers in cyberspace? An investigation of factors influencing electronic exchange. Journal of Computer-Mediated Communication, 5(2), 0-0.

Tabachnick, B.G. and Fidell, L.S. (2007), Using Multivariate Statistics (5th ed.). New York: Allyn and Bacon.

Thamizhvanan, A., \& Xavier, M. J. (2013). Determinants of customers' online purchase intention: an empirical study in India. Journal of Indian Business Research, 5(1), 17-32.

Teo, T. S. (2001). Demographic and motivation variables associated with Internet usage activities. Internet Research, 11(2), 125-137.

To, P. L., Liao, C., \& Lin, T. H. (2007). Shopping motivations on Internet: A study based on utilitarian and hedonic value. Technovation, 27(12), 774-787.

Van der Heijden, H., \& Verhagen, T. (2004). Online store image: conceptual foundations and empirical measurement. Information \& Management, 41(5), 609-617.

Voss KE, Spangenberg ER, Grohmann B (2003). Measuring the hedonic and utilitarian dimensions of consumer attitude. J Mark. Res. 40(3):310320.

Waldfogel, J., \& Chen, L. (2006). Does Information Undermine Brand? Information Intermediary Use and Preference for Branded Web Retailers*. The Journal of Industrial Economics, 54(4), 425-449.

Wolfinbarger, M., \& Gilly, M. C. (2001). Shopping online for freedom, control, and fun. California Management Review, 43(2), 34-55.

Wolfinbarger, M. and Gilly, M. (2003), "e-TailQ: dimensionalizing, measuring and predicting e-tail quality", Journal of Retailing, Vol. 79, pp. 18398.

y Monsuwé, T. P., Dellaert, B. G., \& De Ruyter, K. (2004). What drives consumers to shop online? A literature review. International journal of service industry management, 15(1), 102-121.

\section{Web References}

Press Releases (2013), India's Low E-Commerce Numbers Mask the Internet's Huge Impact on Purchase Decisions. [Online] Available: http://www.bcg.com/media/PressReleaseDetails.aspx?id=tcm:12-132905. (Accessed on 30/10/2014)

Internet World Stats 2014 available [Online] Available: http://www.internetworldstats.com/top20.htm.(Accessed on 30/10/2014)

Jitender Miglani (2014), India Online Retail Forecast, 2013 To 2018. [Online] Available: http://www.forrester.com/India+Online+ Retail+Forecast+2013+To+2018/fulltext/-/E-RES114981. (Accessed on 30/10/2014) 